\title{
ФЛОРА ГОЛИЦЬКОГО БОТАНІКО-ЕНТОМОЛОГІЧНОГО ЗАКАЗНИКА БЕРЕЖАНСЬКОГО РЕГІОНУ ЯК РЕЗУЛЬТАТ ІСТОРИЧНОГО ПРОЦЕСУ ГЕОЛОГІЧНОЇ ТРАНСФОРМАЦІЇ ТЕРИТОРІЙ, ЕВОЛЮЦІЇ ВИДІВ ТА ЕКОЛОГІЧНИХ ГРУП ОРГАНІЗМІВ, ЕКОТОННОГО ЕФЕКТУ ТА АНТРОПІЧНОГО НАВАНТАЖЕННЯ
}

\section{Гловин Н. М., Мартиненко Ж. О.}

\section{ВСТУП}

Екологічні проблеми сьогодення визначають одне 3 найважливіших питань, що стоїть перед людством, - збереження природи як середовища існування усього живого. У зв'язку із антропічною трансформацією довкілля важливого значення набуває питання вивчення флорорізноманіття територій, максимально насичених рідкісними і зникаючими видами, 3 метою встановлення динаміки біоценозів, визначення ступеня їх деградації та можливостей ресурсовикористання та відновлення.

Такими специфічними територіями можна вважати екотони. Екотонам властивий винятково високий рівень біологічної різноманітності, особливо коли вони займають значні площі і є достатньо стабільними протягом тривалого часу, що пояснюється явищем екотонного ефекту підвищенням видової насиченості внаслідок перекривання екологічних амплітуд різних екологічних і систематичних груп 1 .

У нашому дослідженні ми вивчали флору Волино-Поділля, що розвивалась 3 кінця міоцену на звільненій від вод Сарматського моря суші, заселеній давніми флористичними палеокомплексами. На території відмічаються залишки дуже давніх флорокомплексів, тобто груп глибоко реліктових видів, міоценових залишків, яких залишилось дуже мало, значно більшу частину складають автохтонні елементи пізніших етапів формування флори. Значна кількість $є$ аллохтонних видів, мігрантів сусідніх флор (формується екотон) різного віку і різних періодів. Виникають нові раси молодого віку, адвентивні види. При цьому в майбутньому флори густонаселених територій все більше приймають синантропний характер ${ }^{2}$.

\footnotetext{
${ }^{1}$ Барна М.М., Царик Л.П., Черняк В.М. і ін. Голицький ботаніко-ентомологічний заказник загальнодержавного значення. Тернопіль : Лілея, 1997. С. 5-6.

2 Заверуха Б. В. Квітограй Голиці. Рідна природа. 1988. № 3. С. 15-16.
} 
Виконаний нами аналіз досліджень науковців у галузі флорогенезисної інформації щодо території Опілля дозволяє вважати високу ступінь давності їх формування та поетапність розвитку біоти протягом неоген-четвертинного відрізку геологічної та екологічної історії. Природна флора досліджуваних регіонів на цей час сформована як результат історичного процесу геологічної трансформації територій, еволюції видів та екологічних груп організмів, екотонного ефекту та антропічного навантаження. Тому виникає питання про ступінь деградації, здатність до самовідновлення, доцільність та рівень заповідання цих територій та водночас про практичне використання унікальних фіторесурсів у діяльності людини.

Метою дослідження є визначення ефективності розробки наукових основ раціонального використання природних ресурсів та ресурсовідтворення біоценозів. Їх комплексна охорона неможлива без грунтовного вивчення рослинного світу - біоенергетичної основи функціонування біосфери як у регіональному, так i планетарному масштабах. У зв'язку з цим вивчення фітобіоти і шляхів фітосозології, розробка основ прогнозування флористичних $\mathrm{i}$ ценотичних змін у процесі зростаючого антропогенного впливу на всі елементи фітосфери має важливе значення.

Завданням дослідження $\epsilon$ вивчення сучасного стану флорорізноманіття і видового багатства екотонів, розробка наукових основ їх охорони та можливостей практичного використання, що $є$ актуальним питанням сучасної екології.

Об'єктами вивчення були природні популяції флоронаселення вищих спорових і квіткових рослин екотонної території Голицького ботаніко-ентомологічного заказника Бережанського регіону у всьому їх видовому i еколого-ценотичному різноманітті. Особливу увагу приділяли дослідженню екологічних чинників формування і трансформації екотонів, видового складу вищих спорових і квіткових рослин у межах екотонів та суміжних територій, еколого-флористичної характеристики фітоугруповань, визначення рівня біорізноманіття, ступеня деградації та перспектив ресурсовикористання Голицького ботаніко-ентомологічного заказника Бережанського регіону.

\section{1. Фізико-географічні умови, флорорізноманітність, системний та ценоекологічний аналіз флори \\ Голицького ботаніко-ентомологічного заказника}

Голицький ботаніко-ентомологічний заказник - частина Подільського горбогір'я. Він розташований між селами Куряни і Демня в південній частині Бережанського району Тернопільської області. Територія заказника витягнута вузькою смугою з північного заходу на південний схід приблизно на 2270 м. Середня ширина заказника близько 160-240 м, у найширшому місці 400 м, а в найвужчому - 60 м. 
Загальна площа 60 га. Ця територія, за класифікацією Б.В. Заверухи, знаходиться в Опільському районі. На заході вона межує з Північноопільським підрайоном, на сході - із Західноподільським районом, Західно-Подільсько-Приопільським підрайоном ${ }^{3}$.

У геоструктурному відношенні територія заказника розміщена в межах Волино-Подільської плити. В геологічній будові території Голицького заказника беруть участь осадові породи верхнього протерозою, палеозою, мезозою і кайнозою, які залягають на розмитій поверхні кристалічного фундаменту платформи. Найдавнішими утвореннями, які виходять на поверхню на території заказника, $є$ відклади крейдової системи мезозойської групи, які утворилися близько 70 млн років тому. Вони представлені білими і сірими мергелями. Зверху на розмитій поверхні відкладів крейдової системи залягає шар щільних, місцями глинистих літотамнієвих вапняків тортонського ярусу неогенової системи. На вершині гори товщина морських верхньокрейдових і неогенових відкладів покривається невеликим шаром четвертинних лесоподібних суглинків $\mathrm{i}$ лесів, на яких утворилися сучасні грунти. На схилах четвертинні утворення представлені елювіально-делювіальними відкладами різної потужності і складу, на яких розвиваються сучасні грунти - чорноземи неглибокі карбонатні середньо- i слабозмиті, дерново-карбонатні середньоі слабозмиті, сірі опідзолені середньозмиті в поєднанні з сильнозмитими ${ }^{4}$.

За формою існуючого рельєфу територія заказника належить до геоморфологічного підрайону розчленованої височини Опілля, що $\epsilon$ своєрідним геоморфологічним районом, де повністю відсутні пластові форми рельєфу, причому для нього властива виняткова розчленованість, яка зумовлює деяку подібність Опілля з передгірними районами. В ландшафті чітко виділяються окремі горби, що утворюють гряди, які спрямовані з північного заходу на південний схід. Схили горбів переважно круті, еродовані. Особливо це виражено в межиріччі Золотої Липи. Деякі схили досягають крутизни 20,5 і більше.

Рельєф Голицького ботаніко-ентомологічного заказника формується під впливом взаємодії двох протилежно спрямованих сил - ендогенних i екзогенних. Ендогенні створили основні нерівності земної поверхні морфоструктури. Гора Голиця входить у ланцюг горбогірних кряжів 3 округлими вершинами. Ця грядова смуга 3 абсолютними висотами понад 400 м має асиметричну будову схилів - північно-східний схил пологий, а південно-західний високий i крутий. На цьому схилі г. Голиця розташована основна частина заказника. Тільки невелика частина його території розташована на західному схилі ${ }^{5}$.

3 Заверуха Б.В. Квітограй Голиці. Рідна природа. 1988. № 3. С. 14.

4 Заверуха Б.В. Квітограй Голиці. Рідна природа. 1988. № 3. С. 16-17.

Сушко Н. Географія рідкісних рослин Західного Поділля. Студентський науковий вісник. Тернопіль, 2001. № 4. С. 35-36. 
Екзогенні процеси, що зумовлені дією поверхневих вод (тимчасовими і постійними водотоками), вітру, рослинних і тваринних організмів та інших факторів, діючи на ці морфоструктури, урізноманітнюють їх поверхню, утворюючи морфоскульптури. Під дією тимчасових водотоків на схилі заказника утворилися балки, вимоїни і невеликий обрив. Незначний вплив на рельєфотворення має постійний водний потік у межах заказника.

На краю лісового масиву Голицького заказника відмічена максимальна точка висотою 408 м. Мінімальні висоти на території заказника становить 307 м, відмічене у підніжжі схилу. Амплітуда висот на території заказника становить 101 м, що свідчить про велику крутизну схилу г. Голиця, яка має такі загальні характерні риси: схил має південно-західну експозицію; опуклий за формою; має крутизну понад 30 ; ускладнений діяльністю тимчасових і постійних водотоків ${ }^{6}$.

Кліматичні умови заказника можна вважати сприятливими для зростання надзвичайно великої видової різноманітності рослин. Територія Голицького заказника належить до Західно-Свропейської кліматичної провінції, з більш вологим і помірно теплим кліматом. Заказник знаходиться в смузі атлантично-континентального клімату, характерними рисами якого є: значна кількість опадів; помірні річні амплітуди температури повітря не перевищують $24^{\circ} \mathrm{C}$; м'яка зима 3 частими відлигами і постійним сніговим покривом; помірно тепле літо 3 достатньою кількістю опадів під час вегетаційного періоду без стійких атмосферних посух і суховіїв ${ }^{7}$.

Найбільший вплив на формування клімату мають відроги Азорського та Сибірського антициклонів, південні сектори атлантичних циклонів та північні окраїни південних циклонів. У літній період переважає північно-західний перенос повітряних мас, що спричиняє пом'якшення температури. На Бережанщину в зимовий період холодні вітри Азіатського антициклону приходять значно ослабленими і не мають значного впливу на формування мікроклімату заказника.

Мікрокліматичні особливості схилу г. Голиця характеризуються вищими показниками температури повітря від загальнорайонних показників. Максимальна температура повітря становить $20^{\circ} \mathrm{C}$, а мінімальна в січні становить $-4^{\circ} \mathrm{C}$. Середня річна температура повітря на $2{ }^{\circ} \mathrm{C}$ вища від середньорічної Бережанського району. Добовий хід

${ }^{6}$ Сушко Н.О. Історія вивчення фітобіоти наземних екотонів Кременецьких гір і гори Голиця, що на Опіллі. Наукові записки Тернопільського наиіонального педагогічного університету ім. Володимира Гнатюка. Серія: Біологія. Тернопіль, 2005. № 1-2 (25). C. 154-155.

Курант В.З., Барна М.М., Кваша В.І. Дослідження флори і фауни Західного Поділля: матеріали II регіональної науково-практичної конференції, присвяч. 15-річчю створення Голицького біостаціонару ТНПУ ім. В. Гнатюка (24-25 трав. 2013 р. с. Гутисько, Бережанського р-ну Тернопільської обл. Тернопіль : ТНПУ, С. 11. 
температури на цьому схилі змінюється поступово. Безморозний період триває 119-200 днів. Вегетаційний період триває від 206 до 208 днів. Протяжність періоду активної вегетації 3 середньодобовими температурами вище $10^{\circ} \mathrm{C}$ становить 156-157 днів, 90-98 днів становить період 3 температурами вище $15^{\circ} \mathrm{C}$. Сума додатних температур повітря вище $10^{\circ} \mathrm{C}$ становить $2400^{\circ} \mathrm{C}$.

Заказник знаходиться в області значного зволоження. Річна кількість опадів становить 596-650 міліметрів. На території заказника випадає більше опадів, тому що схил гори, на якому знаходиться заказник, - навітряний. Тут переважають вітри західного, південносхідного, північно-західного і південного румбів. Ці вітри приносять вологі повітряні маси. Середня швидкість вітру не перевищує 3 м/сек. Найбільша швидкість вітру весною - 3,6 м/сек, і восени - 3,5 м/сек. Коефіцієнт зволоження 1.0-1.1, що є достатнім ${ }^{8}$.

Територія заказника належить до Волино-Подільського артезіанського басейну. В заказнику представлені: елювіальноделювіальний водоносний горизонт глибиною залягання води 7-10 м. За хімічним складом води горизонту належать до гідрокарбонатнокальцієво-магнієвого типу 3 мінералізацією 1 г/л; міоценовий водоносний горизонт з глибиною залягання води 5-30 м, за хімічній складом води горизонту належать до гідрокарбонатно-кальцієвого типу - сантуронський горизонт знаходиться на глибині 10-40 м. Води відносять до гідрокарбонатно-кальцієвого типу з мінералізацією 0,30,5 г/л. На території заказника спостерігаються виходи підземних вод на денні поверхні в східній частині. На схилі західної експозиції спостерігається вихід трьох джерел, які у верхній частині течії об'єднуються, утворюючи постійний водотік. У східній частині заказника також $є$ вихід підземних вод на денну поверхню В місці виходу підземних вод утворилася заболочена ділянка площею $200 \mathrm{~m}^{2}$. 3 цієї ділянки витікає два струмки довжиною 75 м і 52 м. У межах заказника вони просочуються в грунт. На схід від цієї ділянки є вихід підземних вод у вигляді джерела. Води заказника майже не забруднені, тому що їх виходи $€$ на водороздільних лініях.

Далі у дослідженні йдеться про фіторізноманіття екотону Голицького ботаніко-ентомологічного заказника. Рослинність Голицького заказника представлена лісовими, лучно-степовими лучними і болотними фітоценозами. Лісові масиви займають північнозахідні схили г. Голиця та іiі вершину. Вони представлені формацією граба звичайного у складі субформації буково-грабових і дубовограбових лісів. У Голицькому заказнику фрагментарно представлені

8 Сушко Н.О. Біорізноманіття екосистеми Кременецьких гір як прояв формування екотону. Наукові записки Тернопільського держ. пед. ун-ту. Серія : Географія. Тернопіль, 2004. № 2. Ч.2. С. 255-260 
лучні угрупування, а на місцях виходу підземних і грунтових вод болотні фітоценози ${ }^{8}$. На території Голицького ботанікоентомологічного заказника ліс займає північно-західні схили та вершину площею 0,8 га $(1,3 \%$ від загальної площі території). Він представлений формацією Carpineta betulus у складі субформації Fageto-Carpineta. Домінуючими породами є Carpinus betulus (вік 5070 років, $\mathrm{h}-17-20$ м., d - 18 см., 2-3 клас бонітету) та Fagus sylvatica (вік 50-60 років, $\mathrm{h}-22-24 \mathrm{M.}, \mathrm{d}-35 \mathrm{cm.,} 1$ клас бонітету). У склад деревостану входять також Quercus robur (вік 70-100 років, $\mathrm{h}-23-$ 25 м., d - 32-48 см., 2 клас бонітету), Betula pubescens, Tilia cardata, Fraxinus excelsior, Acer platanoides, A. pseudoplatanus. Зімкнутість крон - 0,6-0,7. Підріст представлений в основному грабом. Підлісок утворюють: Corylus avellana, Euonymus verrucosa, E.europaea, Frangula alnus, Sambucus nigra тощо. У трав'яному покриві зустрічаються: Dactylis glomerata, Festuca pratensis, Aegopodium podagraria, Polygonatum multiflorum, P.odoratum, Convallaria majalis, Asarum europaeum, Carex sylvatica та інші. Густота трав'яного покриву 35-40\%. 3 весняних ефемероїдів тут поширені: Anemone nemorosa, A.ranunculoides, Hepatica nobilis. Значним флористичним різноманіттям відрізняється евтотрофне карбонатне болото площею 0,3 га (0,5\% від загальної площі території), яке знаходиться на південно-західному схилі гори. 3 деревних порід тут росте Salix caprea L. У трав'яному покриві 3 квіткових рослин тут зустрічаються: Molinia caerulea, Phragmites australis, Carex acuta, Eriophorum polystachion, Succisa pratensis, Potentilla erecta та інші. Численна родина Orhidaceae представлена такими видами: Gymnadenia conopsea, Orchis morio, O. militaris, Dactylorhiza majalis, D. sambucina, Epipactis palustris. Ha болоті є виходи двох джерел 9 .

Майже всю територію екотону займають лучно-степові фітоценози - 58,9 га (98,2\% від загальної площі території). Вони представлені формаціями Herbeto-Cariceta, Stipeta pulcherrimae, Herbeto-Brachypodiumeta, Herbeto-Brizeta. Найчастіше зустрічається формація різнотравно-осокова, на чорноземних неглибоких карбонатних середньозмитих грунтах. Травостій тут досить густий, проективне покриття 80-90\%. Домінує Carex humilis. Травостій двоярусний - I-ий ярус - до 65см. заввишки, покриття $45 \%$. Його складають: Elytrigia intermedia - 11\%, Anthericum ramosum - 5\%, Bromopsis inermis $-4 \%$, Centaurea scabiosa $-1 \%$, Senecio besseranum тощо. II-ий ярус - до 40 см., утворює: Carex humilis - 23\%, Phleum

\footnotetext{
${ }^{9}$ Сушко Н.О. Історія вивчення фітобіоти наземних екотонів - Кременецьких гір і гори Голиця, що на Опіллі. Наукові записки Тернопільського національного педагогічного університету ім. Володимира Гнатюка. Серія: Біологія. Тернопіль, 2005. № 1-2 (25). C. 153-155.
} 
phleoides - 11\%, Adonis vernalis - 3\%, Trifolium rubens - 1\%, Helianthemum nummularium, Prunella grandiflira, Iris hungarica.

На південно-західному схилі, на неглибоких карбонатних чорноземах слабозмитих поширена формація Stipeta pulcherrimae. Суцільне покриття утворює Stipa pulcherrima, висотою до $100 \mathrm{~cm}$. Масово цвіте, рясно плодоносить і дає насіннєве відновлення. Значну територію займає формація Herbeto-Brizeta. Травостій зріджений, 4045\% покриття. Домінує Briza media - 18\%. До неї домішуються: Bromopsis inermis $-7 \%$, Elytrigia intermedia - 5\%, Anthericum ramosum $5 \%$, Onobrychis arenaria $-1 \%$, Prunella grandiflora $-1 \%$, Inula ensifolia $1 \%$, Pulsatilla latifolia - $1 \%$ та інші види, покриття яких менше $1 \%$. У формації Herbeto-Brachypodiumeta домінує Brachypodium pinnatum $15 \%$. Густота травостою $60-70 \%$. 3 різнотрав'я зустрічається: Inula ensifolia $-8 \%$, Rhynantus serotinus $-3 \%$, Salvia dumetorum $-3 \%$, Allium oleraceum $-2 \%$, Helianthemum nummularium $-2 \%$, Bromopsis inermis $1 \%$, Trifolium medium $-1 \%$ та інші ${ }^{10}$.

На підставі власних досліджень та відповідних ботанічних праць систематичного аналізу флори Голицького ботаніко-ентомологічного заказника установлено, що флора гори Голиця нараховує понад 285 видів вищих спорових і квіткових рослин (не враховуючи інтродукованих і здичавілих). Вона різноманітна за систематичним складом: об'єднує 3 відділи, 4 класи, 55 родин, 194 родів, 285 видів (табл. 1).

Таблиця 1

\section{Співвідношення основних систематичних груп}

у флорі Голицького заказника

\begin{tabular}{|c|c|c|c|c|c|c|c|}
\hline \multirow[b]{2}{*}{ Відділ } & \multirow[b]{2}{*}{ Клас } & \multicolumn{2}{|c|}{ Родина } & \multicolumn{2}{|c|}{ Рід } & \multicolumn{2}{|c|}{ Вид } \\
\hline & & 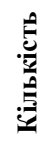 & $s^{\circ}$ & 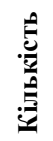 & $b^{\circ}$ & 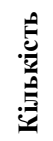 & $s^{0}$ \\
\hline Equisetophyta & Equisetopsida & 1 & 1,8 & 1 & 0,5 & 4 & 1,4 \\
\hline Polypodiophyta & Polypodiopsida & 1 & 1,8 & 1 & 0,5 & 1 & 0,4 \\
\hline \multirow{2}{*}{ Magnoliophyta } & Magnoliopsida & 46 & 83,7 & 157 & 80,9 & 234 & 82,1 \\
\hline & Liliopsida & 7 & 12,7 & 35 & 18,1 & 46 & 16,1 \\
\hline \multicolumn{2}{|c|}{ Всього } & 55 & 100 & 194 & 100 & 285 & 100 \\
\hline
\end{tabular}

Важливим показником флори є іiі систематична структура в межах родини (табл. 2).

${ }^{10}$ Сушко Н.О. Історія вивчення фітобіоти наземних екотонів Кременецьких гір і гори Голиця, що на Опіллі. Наукові записки Тернопільського національного педагогічного університету ім. Володимира Гнатюка. Серія: Біологія. Тернопіль, 2005. № 1-2 (25). C. 155-156. 
Таблиця 2

Систематична структура флори гори Голиця та її складових частин (найчисельніших у видовому відношенні)

\begin{tabular}{|c|c|c|c|c|c|}
\hline \multirow{2}{*}{ № } & \multirow{2}{*}{ Родина } & \multicolumn{2}{|c|}{ Рід } & \multicolumn{2}{|c|}{ Вид } \\
\cline { 3 - 6 } & К-ть & \% & К-ть & \% \\
\hline 1 & Asteraceae & 30 & 15,5 & 39 & 13,7 \\
\hline 2 & Poaceae & 16 & 8,3 & 20 & 7 \\
\hline 3 & Fabaceae & 15 & 7,7 & 21 & 7,4 \\
\hline 4 & Lamiaceae & 14 & 7,2 & 22 & 7,7 \\
\hline 5 & Rosaceae & 14 & 7,2 & 20 & 7 \\
\hline 6 & Apiaceae & 11 & 5,7 & 13 & 4,6 \\
\hline 7 & Ranunculaceae & 8 & 4,1 & 13 & 4,6 \\
\hline 8 & Scrophulariaceae & 7 & 3,6 & 11 & 3,9 \\
\hline 9 & Liliaceae & 7 & 3,6 & 8 & 2,8 \\
\hline 10 & Orchidaceae & 6 & 3,1 & 9 & 3,1 \\
\hline 11 & Coryophyllaceae & 5 & 2,6 & 7 & 2,4 \\
\hline 12 & Borraginaceae & 4 & 2,1 & 7 & 2,4 \\
\hline 13 & Brassicaceae & 4 & 2,1 & 4 & 1,4 \\
\hline 14 & Dipsacaceae & 3 & 1,6 & 4 & 1,4 \\
\hline 15 & Euphorbiaceae & 2 & 1 & 6 & 2,1 \\
\hline 16 & Campanulaceae & 2 & 1 & 5 & 1,7 \\
\hline 17 & Rubiaceae & 2 & 1 & 4 & 1,4 \\
\hline 18 & Cyperaceae & 2 & 1 & 4 & 1,4 \\
\hline 19 & Primulaceae & 2 & 1 & 3 & 1,1 \\
\hline 20 & Caprifoliaceae & 2 & 1 & 3 & 1,1 \\
\hline & Bcboro & 156 & 80,4 & 223 & 78,2 \\
\hline
\end{tabular}

У родинному спектрі флори на десять основних родин припадає 176 видів, що становить 61,8\% загальної кількості видів. На перші три родини припадає 80 видів - 28,1\%.

Також ми дослідили ценоекологічний аналіз флори Голицького ботаніко-ентомологічного заказника. Природні види та їх популяції чітко концентруються у групи, які об'єднані між собою спільністю умов зростання і ценотичними взаємовідносинами. Приуроченість їх до певних ценоекологічних умов $\epsilon$ необхідним проявом розчленування флори на певні групи ценоелементів. Такий аналіз дозволяє розкрити особливості та закономірності приналежності певних груп природних видів до певних ценоекологічних умов, показати домінування тих чи інших флороценоекологічних комплексів, їх взаємопроникнення, зробити висновок про генезисні особливості формування певної флори i формування екотонів. Флоронаселення Голицького ботанікоентомологічного заказника об'єднане десятьма флороценотипами: неморальний флороценотип об'єднує 107 (37,5\%) флороценоелементів, представлений різними життєвими формами: Fagus sylvatica L., Quercus robur L., Carpinus betulus L., Betula pubescens Ehrh., Corylus avellana L.; Anemone nemorosa L., A. ranunculoides L., Actaea spicata L.; Dentaria glandulosa Waldst., Euphorbia amygdaloides L., Daphne mezereum L., Melittis sarmatica Klok., Aposeris foetida (L.) Less., Lilium martagon L. та інші (табл. 3). 
Луго-степовий флороценотип нараховує 58 (20,4\%) флороценоелементів: Adonis vernalis L., Linum flavum L., Pulsatilla latifolia Rupr., P. grandis Wend., Trifolium montanum L., Centaurea scabiosa L., Scorzonera purpurea L. Helianthemum ovatum (Viv.) Dun, Filipendula vulgaris Moench., Medicago procumbens Bess. та інші.
Лучний
флороценотип
представлений
40
$(14 \%)$ флороценоелементами: Poa pratensis L., Festuca pratensis Huds., Trifolium pretense L., T. medium L., T. repens L., Coronaria flos-cyculi (L.) A. Br., Lysimachia nummularia L. Melilotus albus Medik. та інші.

Таблиця 3

Ценоекологічна характеристика флори екотону гори Голиця (за Б.В. Заверухою)

\begin{tabular}{|c|c|c|c|}
\hline № п/п & Флороценотипи & Кількість видів & \% \\
\hline 1 & Неморальний & 107 & 37,5 \\
\hline 2 & Луго-степовий & 58 & 20,4 \\
\hline 3 & Лучний & 40 & 14 \\
\hline 4 & Агрорудеральний & 24 & 8,4 \\
\hline 5 & Гігро-гідроболотяний & 17 & 6 \\
\hline 6 & Кальцепетрофільний & 12 & 4,2 \\
\hline 7 & Степовий & 11 & 3,9 \\
\hline 8 & Псамофільний & 6 & 2,1 \\
\hline 9 & Ксерочагарниковий & 6 & 2,1 \\
\hline 10 & Боровий & 4 & 1,4 \\
\hline & Всього & 285 & 100 \\
\hline
\end{tabular}

Агрорудеральний флороценотип (сегетальні та рудеральні бур'яни) об'єднує 24 (8,4\%) флороценоелементів: Equisetum arvense L., Papaver rhoeas L., Sisimbrium altissimum L., Euphorbia cyparissias L., E. helioscopia L., Vicia cracca L., Convolvulus arvensis L., Linaria vulgaris Mill., Melampyrum arvense L., Plantago major L., Salvia verticillata L., Carduus akanthoides L., C. crispus L., Sonchus arvensis L., Aretium tomentisum Mill., Artemisia absentheum L., A. vulgaris L., Matricaria perforata Merat., Stenactis annuus Nees. та інші. Гігро-гідроболотяний флороценотип нараховує 17 (6\%) флороценоелементів: Potentella erecta (L.) Raeusch., Equisetum hyemale L., Phraomites austrialis Trin. ex Steud, Stachys palustris L., Juncus inflexus L., Eriophorum polystachion L., Molinia careulea L., Epipactis palustris (L.) Cran., E. atrorubens (Hoffm. ex Bernh.) Schult. та інші.

Кальцепетрофільний флороценотип включає 12 (4,2\%) флороценоелементів: Carlina vulgaris L., C. onopordifolia Bess. ex Szaf., Kulcz. et Pawl., Alysum gmelinii Jord., Euphorbia volhynica Bess. ex Szaf., Kulcz., Jurinea calcarea Klok., Allium strictum Schrad., Teucriym montanum L. та інші.

Степовий флороцентип об'єднує 11 (3,9\%) флороценоелементів: Euphorbia seguierana Neck., Trinia multicaulis Schischk., Stipa pulcherrima C. Koch., Festuca valesiaca Gand., F. rupicola Heuff., Asperula cynanchica L., Phleum phleoides (L.) Karst., Polygala podolica DC. та інші (рис. 1). 


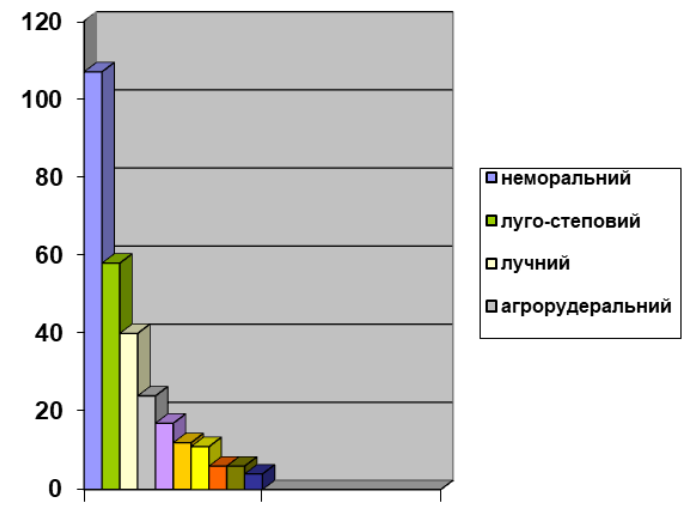

\section{Рис. 1. Співвідношення флороценотипів екотону гори Голиця (за Б.В. Заверухою) ${ }^{11}$}

Псамофільний флороценотип нараховує 6 (2,1\%) флороценоелементів: Cardaminopsis arenosa (L.) Hayk., Potentilla areneria Borkh., Onobrychis arenaria (Kit) DC., Rhinanthus serotinus (Schoenh.) Oborny., Thymus serpyllum L., Hieracium pilosella L.

Ксерочагарниковий флороценотип об'єднує 6 (2,1\%) флороценоелементів: Cerasus fruticosa L., Prunus stepposa Kotov, Rosa tomentosa Smith., R. czackiana Bess., R. jundzillii Bess., Crataegus curvisepala Lindm.

Боровий флороценотип включає 4 (1,4\%) види: Rumex acetosella L., Daphne cneorum L., Peucedanum oreoselinum (L.) Moench., Solidago virgaurea $\mathrm{L}$.

\section{2. Огляд ендемів та реліктів досліджуваного регіону}

У другому розділі нашого дослідження специфічності флори певного регіону важливе значення має явище ендемізму. А.І. Толмачев (1974), В.М. Васілєв (1963) вказують, що частка ендеміків у певній флорі характеризує ступінь індивідуальності цієї флори. Деякі фрагментарні відомості про ендеми окремих ділянок досліджуваних територій знаходимо в працях М.О. Бухало (1964), Г.О. Кузнецової (1963), Г.С. Куковиці (1970), I.I. Мороз, С.С. Харкевича (1973), Ю.Р. Шеляг-Сосонко, Г.С. Куковиці (1974), Б.В. Заверухи $(1965,1985)$, B.I. Мельник (2000) та інших ${ }^{12}$.

Надзвичайно цінними у науковому відношенні $є$ екотон Голицького ботаніко-ентомологічного заказника, де збереглися рідкісні види

11 Заверуха Б. В. Квітограй Голиці. Рідна природа. 1988. № 3. С. 18-19

12 Сушко Н.О. Історія вивчення фітобіоти наземних екотонів Кременецьких гір і гори Голиця, що на Опіллі. Наукові записки Тернопільського національного педагогічного університету ім. Володимира Гнатюка. Серія: Біологія. Тернопіль, 2005. № 1-2 (25). C. 153-154. 
рослин - палеоендеми, залишки минулих геологічних епох. Флора досліджуваних регіонів є дериватом глибокореліктової флори. 3 кінця нижнього сармату відбувався відступ сарматського моря. У зв'язку з цим досліджувана територія стає сушею. Протягом усього третинного періоду відбувалося поступове охолодження. На межі олігоцену та міоцену пройшли зміни клімату, в результаті якого на зміну субтропічній прийшла арктотретинна, або тургайська, помірна флора з листопадних порід. Верхньоміоценові флори поряд з окремими субтропічними видами переважно складалися 3 флори лісів помірного поясу: дуба, клена, берези, глоду та інших. Особливо процес охолодження проявлявся у пліоцені, коли рослинність набуває вигляду, близького до сучасного. У верхньому міоцені і пліоцені на території екотонів панували давні ліси, які у зв'язку 3 аридизацією клімату трансформувалися у давній саваноїдний лісостеп, а далі у степ в середині пліоцену (М.В. Клоков, 1968). Зміни клімату в бік зволоження і деякого похолодання привели до панування хвойних лісів 3 домішком неморальних елементів. В міндельську епоху встановлюється сучасна лісостепова флора, пізніше лісостеп перекривається тіньовими бучинами, які деградують до кінця плейстоцену i в кінці плейстоцену на цій території встановлюється сучасна лісостепова флора.

На території Голицького ботаніко-ентомологічного заказника виявлено 22 релікти (7,7\% від загальної кількості видів) та 58 ендемів $(20,4 \% \text { від загальної кількості видів })^{13}$. Більшість ендеміків $\epsilon$ ценоелементами кальцеопетрофітона, кальцеопетрофільних лугостепових ділянок, степових i кальцеопетрофільних чагарникових угруповань. Формування основного автохтонного ядра флори проходило в надрах давнього палеокальцепетрофітона, на основі якого виникли основні пракомплекси: саваноїдно-лучно-степовий, давньостеповий, давньочагарниковий (Б.В. Заверуха, 1985) ${ }^{14}$. Другим базисом формування одного із основних компонентів флори був пранеморальний і прочагарниковий.

Під час аналізу реліктів та ендемів досліджуваного регіону особливу увагу заслуговує один із найбільш рідкісних для всієї території України степових видів - відкасник татарниколистий, релікт, який дійшов до нас з часів третинного періоду і на цей час зникає через неконтрольоване випасання худоби, заліснення схилів та часті весняні випалювання травостою.

Дев’ятиси́л татарниколи́стий, або відка́сник татарниколи́стий (Carlina onopordifolia) 3 родини Айстрові. Багаторічна монокарпічна трав'яниста рослина. Стебло майже нерозвинуте, дуже вкорочене. Розетка прикореневих глибокоперисто надрізаних колючих листків розпростерта на поверхні грунту. Суцвіття - кошик (діаметр бл. 20 см). Внутрішні

${ }^{13}$ Saatkamp A., Aggre L., Dutoit T., Poschod P. Germination traits explain soil seed persistence across species; the case of Mediterranean annual plants in cereal fields. Ann. Bot, 2011. Vol. 107. P. 417-418. doi: 10.1093/aob/mcq255.

14 Заверуха Б.В. Квітограй Голиці. Рідна природа. 1988. № 3. С. 17-18. 
листочки обгортки (завдовжки 6-6,5 см, завширшки 1,7-4 мм) цупкі, лінійні, тонкозагострені, з внутрішнього боку жовтуваті, лискучі. Численні трубчасті квіточки жовтуваті. Сім'янки довгасті, з чубком волосків. Цвіте у серпні. Плодоносить у вересні. Розмножується насінням.

Ареал виду охоплює Подільську, Волинську, Люблінську та Малопольську височини. Цей вид $\epsilon$ центрально-європейським (південно-східна частина Центральноєвропейської флористичної провінції) елементом флори України. В межах Польщі зафіксовано лише п'ять локалітетів виду. Цей вид близько споріднений лише 3 нагірно-середземноморськими представниками роду, тобто має зв'язки 3 одним із стародавніх центрів формування флори і дійшов до нас 3 кінця третинного періоду, коли тут ще панував субтропічний клімат 15 . Сьогодні відкасники селяться лише на південних сонячних схилах, де дуже теплоємкий крейдяно-вапняковий грунт. Це надзвичайно рідкісний, реліктовий вид, занесений до Червоних книг України, Польщі, до списку Бернської конвенції та Червоного списку МСОП. Охороняється на території НПП «Галицький» та в заказниках «Голицький» (Тернопільська обл.), «Чортова гора» (Івано-Франківська обл.), «Лиса гора і гора Сипуха», «Біла гора» (Львівська обл.) ${ }^{16}$.

У наш час цей вид відкасника використовується в народній медицині у вигляді відварів, настоїв та порошків з висушеного кореня яксечогінний та потогінний, а також як протизапальний засіб у разі захворювання нирок, затримці менструацій, під час лікування бронхіту, нашкірних захворювань, нервового виснаження та проти глистів. Наприклад, порошок з розтертого сухого кореня, змішаний з вином, виганяє солітера, а відвар коріння виганяє круглих глистів. Для відвару беруть ложку коріння на півлітра води. Коріння містить у собі ефірну олію, дубильні речовини, смоли, інулін тощо. Ефірна олія кореня має добре виражені антибактеріальні властивості. Корінь відкасника використовують під час лікування безпліддя, онкологічних захворювань, у разі загальної загальмованості функцій кори головного мозку, дисфункції вищої нервової діяльності, пов'язаної з вагітністю. Ці препарати за впливом на нервову систему аналогічні дії вітаміну $\mathrm{B}_{2}$, нетоксичні і не викликають побічних дій. У народній медицині корені виду Radix carlinae, зібрані весною або пізньої осені, використовують внутрішньо у разі запалення сечостатевих органів, ниркових набряків, як антигельмінтний засіб, зовнішньо - при лишаях, для загоювання ран, а також у ветеринарній практиці.

Оскільки C. onopordifolia широко використовуються у медицині та для створення ландшафтних композицій (кам'янистих садів, гірок,

${ }^{15}$ Kholina A. B., Voronkova N. M. Seed Cryopreservation of Some Medicinal Legumes. Botanical Studies. 2013, T. 54, № 33. P. 128-129. DOI: https://doi.org/10.29296/25877313-2018-10-12.

${ }_{16}$ Sledziński S. Pryczynek do flory obwodów Brzezańskiego i Tarnopolskiego oraz czesci przyległych im obwodów Lwowskiego, Złoczowskiego, Czortkowskiego i Stanisławskiego. Spraw. komis. fiziogr. 1874. T. 8. S 67-68. 
рокаріїв), тому для їх збереження необхідно постійно контролювати за станом популяцій, створювати нові заповідні об'єкти, резервати, рекомендувати вирощувати види у ботанічних садах (рис. 2) ${ }^{17}$.

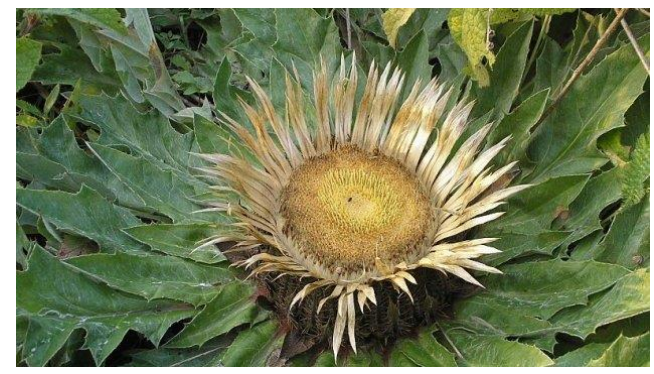

\section{Рис. 2. Дев'ятиси́л татарниколи́стий, або відка́сник татарниколи́стий (Carlina onopordifolia)}

\section{ВИСНОВКИ}

Отже, провівши аналіз досліджень науковців та провівши власні спостереження, ми вважаємо, що:

- екотон Голицького ботаніко-ентомологічного заказника є цінним i цікавим у флористичному, екофітоценотичному та ботанікогеографічному аспектах. Це зумовлено їх геологічною історією, різноманіттям грунтів, материнських порід, значним розчленуванням рельєфу, взаємовпливом двох кліматичних і ботаніко-географічних провінцій (Середземноморської 3 більш вологим кліматом і Східноєвропейської з континентальним кліматом);

- систематичний аналіз флори Голицького ботанікоентомологічного заказника показав, що дана флора нараховує 285 видів вищих спорових і квіткових рослин (не враховуючи інтродукованих і здичавілих), які об'єднують 3 відділи, 4 класи, 55 родин, 194 роди. На десять основних родин припадає 176 видів $(61,8 \%)$ від загальної кількості видів, на перші три родини - 80 видів $(28,1 \%)$. Провідними родинами є Asteraceae (30 родів, 39 видів), Роaceae (16 родів, 20 видів), Fabaceae (15 родів, 21 вид). Положення перших найбагатших родин відповідає типу середньоєвропейських флор, розміщення послідуючих родин вказує на деяке зближення з середземноморським типом;

- майже всю територію Голицького заказника займають лугостепові ділянки - 58,9 га (98,2\% від загальної площі території). Грабово-буковий ліс займає північно-західні схили та вершину, площею 0,8 га $(1,3 \%)$. На південно-західному схилі гори знаходиться евтотрофне карбонатне болото площею 0,3 га (0,5\%).

${ }^{17}$ Рубановська Н.В. Дослідження популяції allium ursinum 1. у західному поділлі (Україна). Scientific Journal "sciencerise: Biological Science” №2 (5)2017. C. 30-31 doi: $10.15587 / 2519-8025.2017 .99449$ 
Також на території заказника виявлено 22 релікти $(7,7 \%)$ та 58 ендемів. Зокрема, С. Onopordifolia $є$ рідкісним, реліктовим червонокнижним видом, який на цей час зникає через неконтрольоване випасання худоби, заліснення схилів та часті весняні випалювання травостою. Для збереження С. Onopordifolia необхідно постійно контролювати стан популяцій, створювати нові заповідні об'єкти, резервати, рекомендувати вирощувати види у ботанічних садах.

\section{АНОТАЦІЯ}

У дослідженні акцентується увага на збереженні біоландшафтного різноманіття та оптимізації функціонально-просторової структури природно-заповідних територій і об'єктів відповідно до особливостей території кожної області. Досліджуваний регіон - екотон Голицького ботаніко-ентомологічного заказника Бережанського регіону, що має біосферне, екологічне, економічне, ландшафтно-естетичне значення. Результатом аналізу досліджень науковців та власних спостережень є докази унікальності флоронаселення екотонів. 3 флори Голицького ботаніко-ентомологічного заказника 23 види $(8,1 \%)$ занесених до Червоної книги України та 41 вид $(14,4 \%)$ регіонально рідкісних. Антропогенний вплив на гору Голиця проявлявся уже 3 раннього

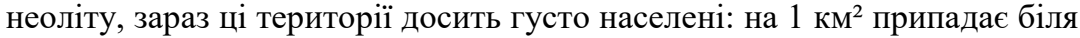
90 осіб за середньої щільності в Україні 85,6 осіб. Більшість природних угідь були перетворені на орні землі. На цей час природні угруповання займають незначний відсоток (біля 20\%), у специфічних екологічних умовах, на скелях, урвищах, балках, ярах, в лісових масивах, а також у флорі синантропних флороценокомплексів, ще збереглися види, які $\epsilon$ джерелом корисної фітосировини. Для збереження унікального флороценокомплексу Голицького ботаніко-ентомологічного заказника необхідно заборонити випас худоби, заготівлю лікарської сировини, зривання квітучих рослин, провести розчистку дерев і чагарників на південних схилах гір, слід розширити площу заказника за рахунок прилеглих територій лісу та болота (Гутисько), як різних за екологічними умовами територій. Доцільно проводити роботу зі створення маточних плантацій рідкісних видів, розширивши генофонд реліктів, ендемів і вимираючих регіонально-рідкісних видів.

\section{ЛITЕРАТУРА}

1. Барна М.М., Царик Л.П., Черняк В.М. і ін. Голицький ботанікоентомологічний заказник загальнодержавного значення. Тернопіль : Лілея, 1997. 64 с.

2. Заверуха Б. В. Квітограй Голиці. Рідна природа. 1988. № 3. C. $14-19$.

3. Курант В.3., Барна М.М., Кваша В.І. Дослідження флори і фауни Західного Поділля: матеріали II регіональної науково-практичної конференції, присвяч. 15-річчю створення Голицького біостаціонару 
ТНПУ ім. В. Гнатюка (24-25 трав. 2013 р. с. Гутисько, Бережанського р-ну Тернопільської обл. Тернопіль : ТНПУ, 2013. 112 с.

4. Рубановська Н.В. Дослідження популяції allium ursinum 1. у західному поділлі (Україна). Scientific Journal "sciencerise: Biological Science” № 2 (5)2017. C. 29-34 doi: 10.15587/2519-8025.2017.99449

5. Сушко Н. Географія рідкісних рослин Західного Поділля. Студентський науковий вісник. Тернопіль, 2001. №4. С. 34-36.

6. Сушко Н.О. Історія вивчення фітобіоти наземних екотонів Кременецьких гір і гори Голиця, що на Опіллі. Наукові записки Тернопільського начіонального педагогічного університету ім. Володимира Гнатюка. Серія: Біологія. Тернопіль, 2005. № 1-2 (25). C. $153-158$.

7. Kholina A. B., Voronkova N. M. Seed Cryopreservation of Some Medicinal Legumes. Botanical Studies. 2013, T. 54, № 33. P. 122-131. DOI: https://doi.org/10.29296/25877313-2018-10-12.

8. Saatkamp A., Aggre L., Dutoit T., Poschod P. Germination traits explain soil seed persistence across species; the case of Mediterranean annual plants in cereal fields. Ann. Bot, 2011. Vol. 107. P. 415-426. doi: $10.1093 / \mathrm{aob} / \mathrm{mcq} 255$.

9. Sledziński S. Pryczynek do flory obwodów Brzezańskiego i Tarnopolskiego oraz czesci przyległych im obwodów Lwowskiego, Złoczowskiego, Czortkowskiego i Stanisławskiego. Spraw. komis. fiziogr. 1874. T. 8. S 49-70.

\section{Information about authors: Glovyn N. M.,}

Candidate of Pedagogic Sciences, Associate Professor of Ecology Department Separated subdivision National University of Life and Environmental Sciences of Ukraine "Berezhany Agrotechnical Institute" 20, Akademicheskaya Str., Berezhany, Ternopil region, 47500, Ukraine

Martynenko Zh. O., Senior Lecturer, Department of Ecology, Environmental Protection and Balanced Environmental Management of the separate unit Separated subdivision National University of Life and Environmental Sciences of Ukraine "Berezhany Agrotechnical Institute" 20, Akademicheskaya Str., Berezhany, Ternopil region, 47500, Ukraine 